\title{
Archaeological Monitoring at Three Prehistoric Locales in Zapata County, Texas
}

Joseph H. Labadie

Follow this and additional works at: https://scholarworks.sfasu.edu/ita

Part of the American Material Culture Commons, Archaeological Anthropology Commons, Environmental Studies Commons, Other American Studies Commons, Other Arts and Humanities Commons, Other History of Art, Architecture, and Archaeology Commons, and the United States History Commons

Tell us how this article helped you.

This Article is brought to you for free and open access by the Center for Regional Heritage Research at SFA ScholarWorks. It has been accepted for inclusion in Index of Texas Archaeology: Open Access Gray Literature from the Lone Star State by an authorized editor of SFA ScholarWorks. For more information, please contact cdsscholarworks@sfasu.edu. 


\section{Archaeological Monitoring at Three Prehistoric Locales in Zapata County, Texas}

Creative Commons License

(c) (i) (8)

This work is licensed under a Creative Commons Attribution-NonCommercial 4.0 International License 
ARCHAEOLOGICAL MONITORING AT THREE PREHISTORIC

LOCALES IN ZAPATA COUNTY, TEXAS

Joseph H. Labadie

Center for Archaeological Research The University of Texas at San Antonio Archaeological Survey Report, No. 170 

ARCHAEOLOGICAL MONITORING AT THREE PREHISTORIC

LOCALES IN ZAPATA COUNTY, TEXAS

Joseph H. Labadie

Center for Archaeological Research The University of Texas at San Antonio( Archaeological Survey Report, No. 170 



\section{ABSTRACT}

Archaeological monitoring at three locales on federal 1 and within the Falcon Reservoir was conducted by the Center for Archaeological Research, The University of Texas at San Antonio, on October 2 and 3, 1986. Machine trenching across each $10 c a l e$ was done by Arco $0 i 1$ and Gas Company, Freer, Texas, in conjunction with the construction of a pipeline which crosses both private and federal 1 ands adjacent to the Beckwith Arm of Falcon Reservoir. Trenching did not adversely affect the integrity of cultural materials at any of the three locales. One of the locales was designated an archaeological site (41 ZP 109), and one archaeological site (41 ZP 108) not previousiy recorded was located. None of the locales or sites meet the eligibility criteria to be nominated to the National Register of Historic Places or to be designated as a State Archeological Landmark. 
ABSTRACT .............................. LIST OF FIGURES ....................... $i$... ACKNOWLEDGMENTS ..............................

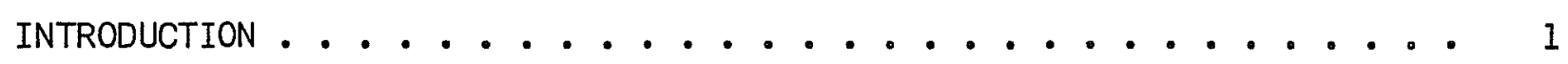

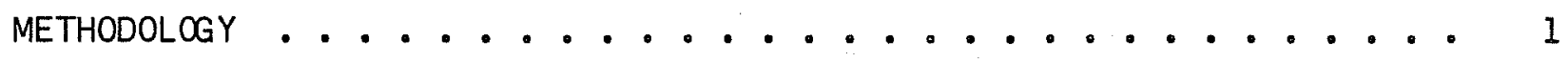

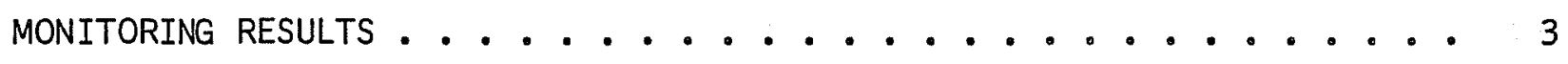

Arco Locale No. 1 . . . . . . . . . . . . 3

ArCo Locale No. 2 ..................... 3

Arco Site No. 3 (4I ZP 109) ..................... 6

CAR-UTSA Site No. I (4l ZP 108) .................. 7

SUMMARY AND RECOMMENDATIONS ........................ 8

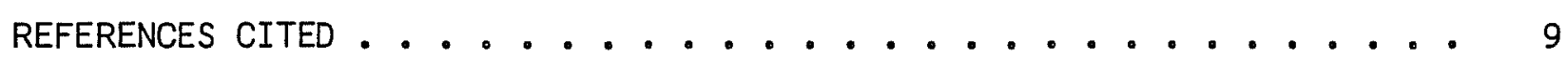

\section{LIST OF FIGURES}

1. Location of the Project Area Pipeline Route and Archaeological Sites and Locales Monitored ............. 2

2. Trench Soil Profiles Observed .............. 4

3. Artifacts Recovered With in and Adjacent to the Arco Right-of-Way . . 5 


\section{ACKNOWLEDGMENTS}

The author thanks Lori Ripple, Arco engineer, for her generous assistance in locating the archaeological locales, and for providing other valuable information. Thanks, also, to the Center for Archaeological Research administrative staff for assistance in the preparation of this report. 


\section{INTRODUCTION}

The Arco $0 i 1$ and Gas Company, Freer, Texas, proposed the construction of a gas pipeline across federal 1 and in the Falcon Reservoir in Zapata County, Texas (Fig. 1). The construction right-of-way, which crosses the Beckwith Arm of the reservoir, was surveyed in its entirety for archaeological sites by Kenneth L. Brown (1986), who reported three possible archaeological "sites." Brown was hesitant to call any of the three locales "sites" due to the paucity of cultural materials identified at each (no site survey forms were filed with the Texas Archeological Research Laboratory [TARL] at that time). The initial reconnaissance survey of federal 1 and within the pipeline project was required for an Archaeological and Historical Impact Assessment, as specified in the Army Corps of Engineers Permit No. 17748.

Archaeological monitoring of construction activities in the vicinity of these three locales was conducted under contract (invoice dated September 30, 1986) with Arco $0 i 1$ and Gas Company by the Center for Archaeological Research at The University of Texas at San Antonio (CAR-UTSA) on October 2 and 3, 1986. The monitoring of construction activities at each locale was required by the Texas Historical Commission based on the recommendations of the earlier onthe-ground survey by Brown (1986:8).

Prior to the commencement of trenching, the entire length of the proposed pipeline route was inspected by Lori Ripple (Arco engineer) and Joe Labadie (CAR-UTSA). The Arco engineer noted the locations for a 11 three locales. The construction right-of-way width across the three areas is 60 feet; approximately 40 feet has been cleared of all trees and surface vegetation by heavy machinery. During the course of the premonitoring survey of the rightof-way, one additional archaeological site was identified.

As a result of the current work, survey forms for 41 ZP 109 (Arco Site No. 3) and 41 ZP 108 (CAR-UTSA Site No. 1) have been filed with the appropriate authorities. Site 41 ZP 108 was overlooked by the initial survey. Arco Locales Nos. 1 and 2 are not considered to be worthy of the designation as an archaeological site, and site survey forms have not been filed for these two areas.

The reader is referred to Brown (1986) for background information on the environment, geology, topography, and previous archaeological research in the vicinity of the Arco pipeline. This report presents only the results of archaeological monitoring at the locales recommended for further work by Brown (1986:8) and the Texas Historical Commission. Basic data on site 41 ZP 108 are also provided.

\section{METHODOLOGY}

Standard archaeological field procedures (Hester, Heizer, and Graham 1975) and documentation procedures (CTA 1981) were adhered to for this project. Activities at each archaeological locale consisted of monitoring the trenching across each "site." Machine trenching at each locale produced a four-foot-deep trench that was ca. 18 inches wide. Backdirt from trenching was visually inspected for any cultural materials (such as bone, shell, and 
This page has been

redacted because it

contains restricted

information. 
1 ithics) but was not screened. Vertical soil profiles at each locale were photographed and drawn. Al 1 field notes, photographs, and other pertinent items concerning this project are on file at the CAR-UTSA 1 aboratory.

\section{MONITORING RESULTS}

Arco Locale No. 1

Arco Locale No. 1 is located on federal 1 and at the western end of the pipeline route (Fig. 1). Brown $(1986: 6)$ recovered two nondiagnostic 1 ith ic artifacts (one utilized flake, one scraper) on the surface in a 3000-squarefoot area within the right-of-way near survey station $36+00$. Subsurface shovel testing by Brown at this locale (number and location of units unspecified) produced no additional artifacts.

Monitoring of the machine trenching at this locale failed to identify any cultural materials in the backdirt. No artifacts were found on the ground surface within this portion of the right-of-way during the pretrenching survey by the CAR-UTSA archaeologist. The vertical soil profile within the trench evidenced a weakly stratified mixture of sand and gravel with no obvious soil horizon development (Fig. 2,a). The lowest parts of the profile contained high proportions of caliche and sandstone.

Brown suggested that cultural materials at this locale were there as a result of erosion from an upland area to the west that was not surveyed. Survey of the upland area by this project tends to confirm Brown's initial impressions. Over 50 chert flakes (mostly primary and secondary hand-hammer flakes) and several biface fragments ( $F i g .3, C, d$ ) were noted within 250 feet of the pipeline center 1 ine, well outside of the right-of-way. No temporal1y diagnostic artifacts were found; however, the size and general technology of the biface fragments suggest Archaic rather than Late Prehistoric origins. It appears that Arco Locale No. 1 is situated on the upland ridge west of the right-of-way and that a 11 cultural materials within the right-of-way have eroded down slope and are no longer in a primary context.

\section{Arco Locale No. 2}

Arco Locale No. 2 is located on federal 1 and between survey stations $48+00$ and $49+50$ within the construction right-of-way (Fig. 1). Brown (1986:6) recovered four 1 ithic artifacts (three flakes, one scraper) from a 250- to 300-foot-long portion of the right-of-way (or 7500- to 9000-square-foot area). No artifacts were recovered from his shovel testing at the site. He also noted that surface topography at this locale was relatively flat and suggested it was a product of wave action associated with the normal pool level of the reservoir (301 feet above mean sea level [MSL]). At the time of Brown's survey (June 3 and 5, 1986), the Beckwith Arm of Falcon Reservoir was 800 feet in width and ca. 4.5 feet in depth (poo 11 evel of 265 feet above MSL). During this current project, the Beckwith Arm was ca. 1200 feet wide and 11.5 feet deep (or 272 feet above MSL). 


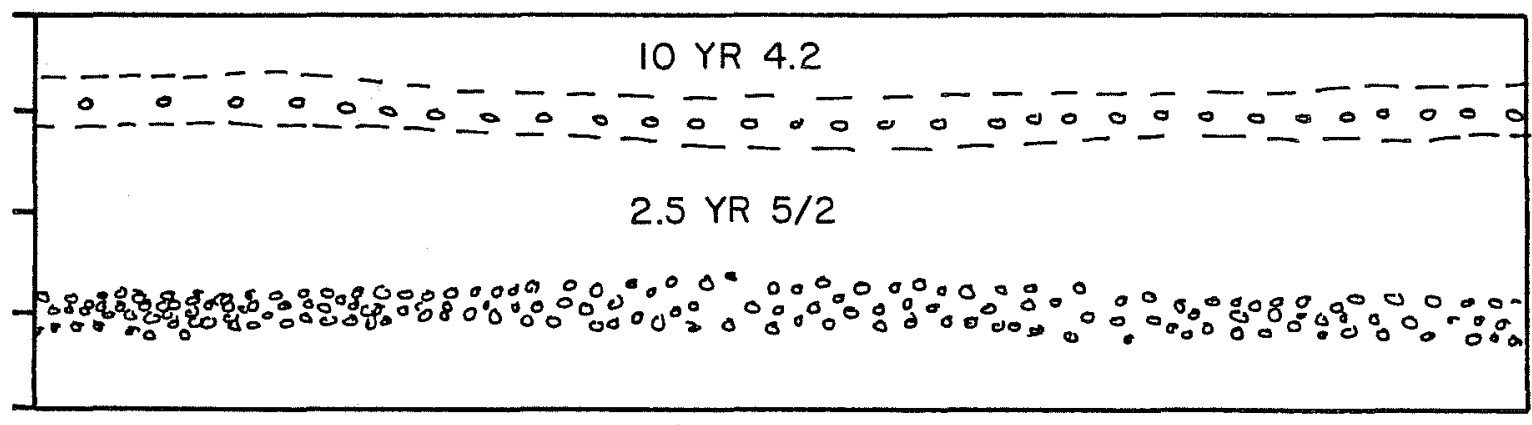

a
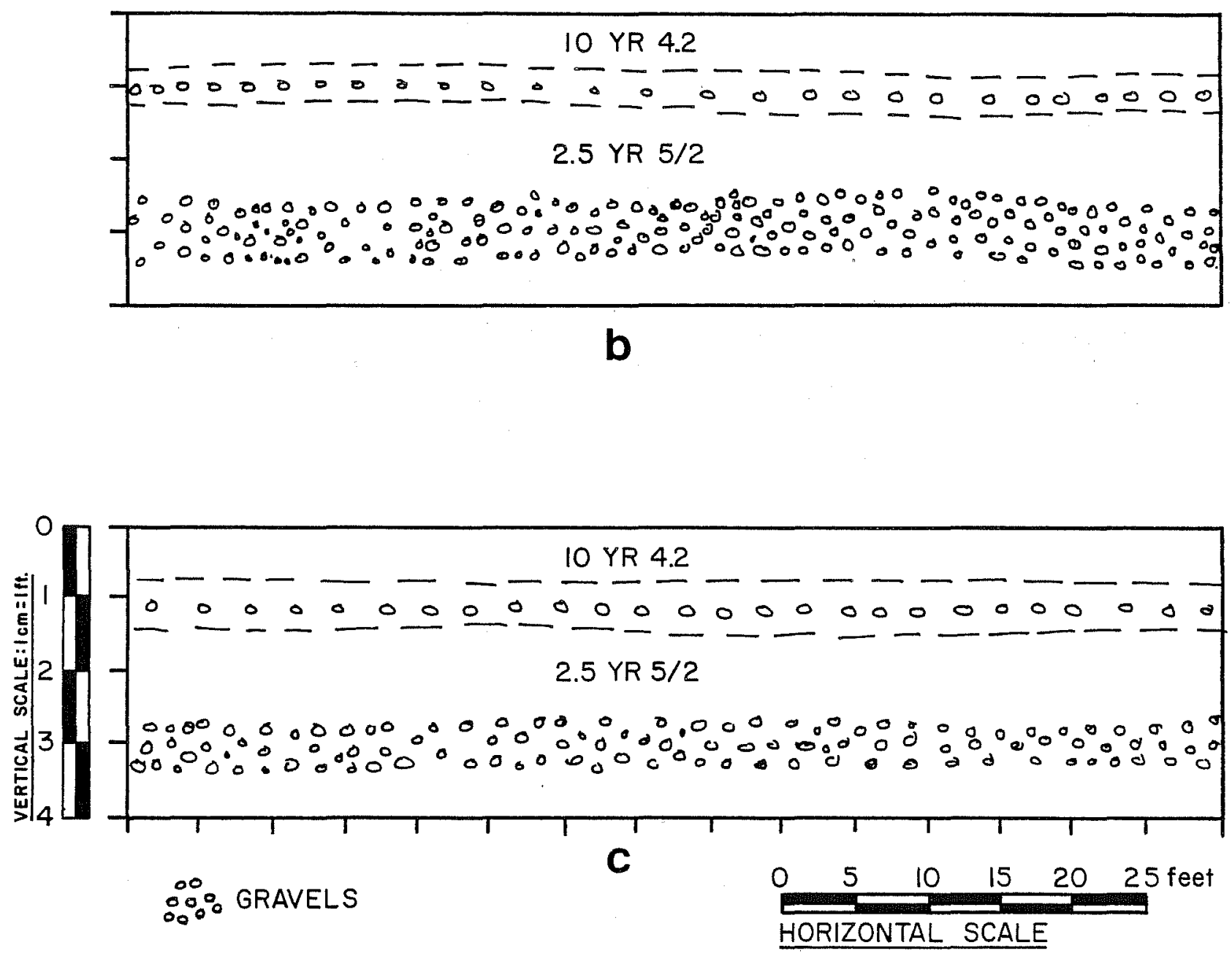

Figure 2. Trench Soil Profiles Observed. a, Arco Locale No. 1; b, Arco Locale No. 2; c, Arco Locale No. 3 (4l ZP 109). 

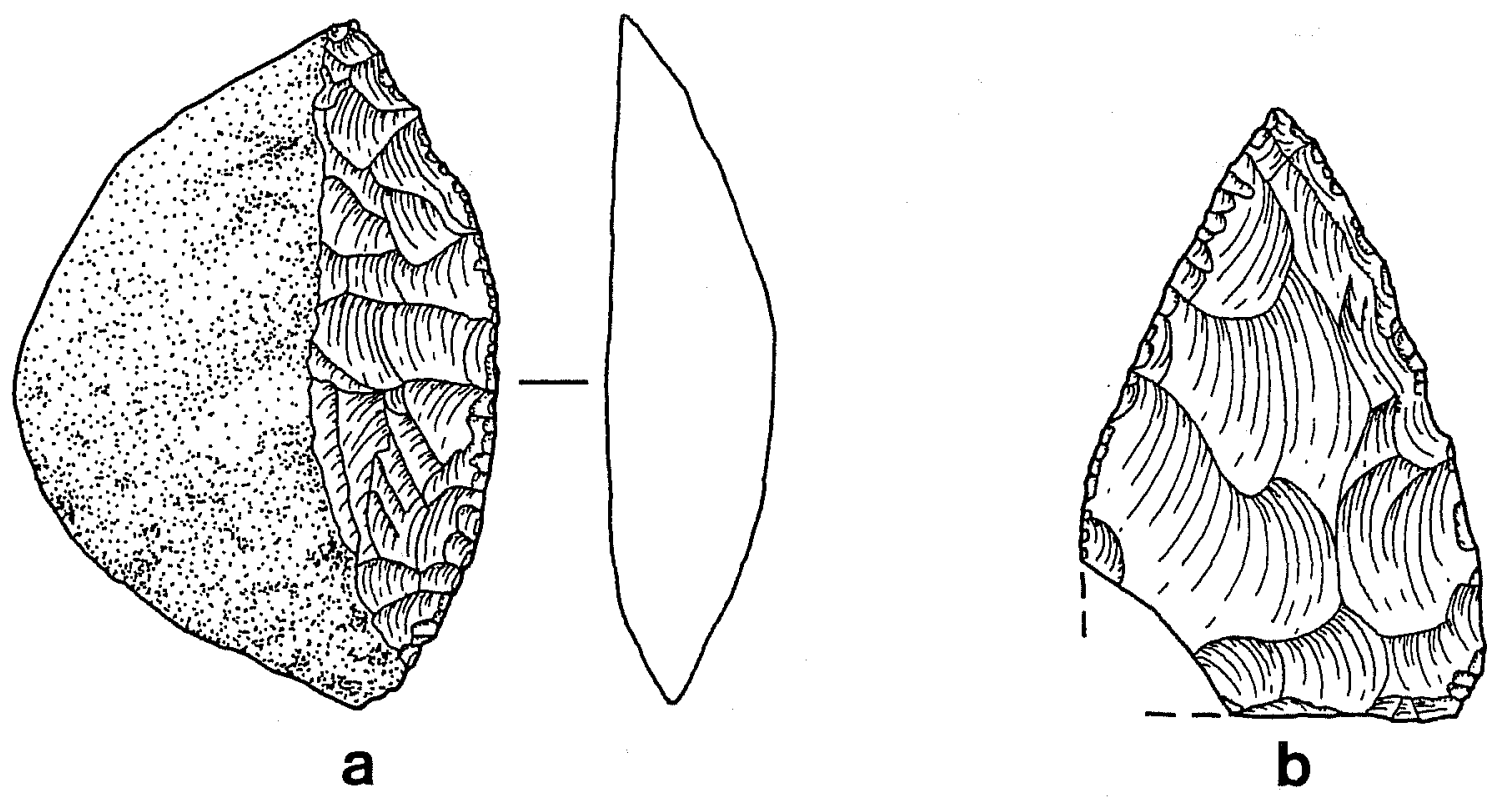

0

$5 \mathrm{~cm}$
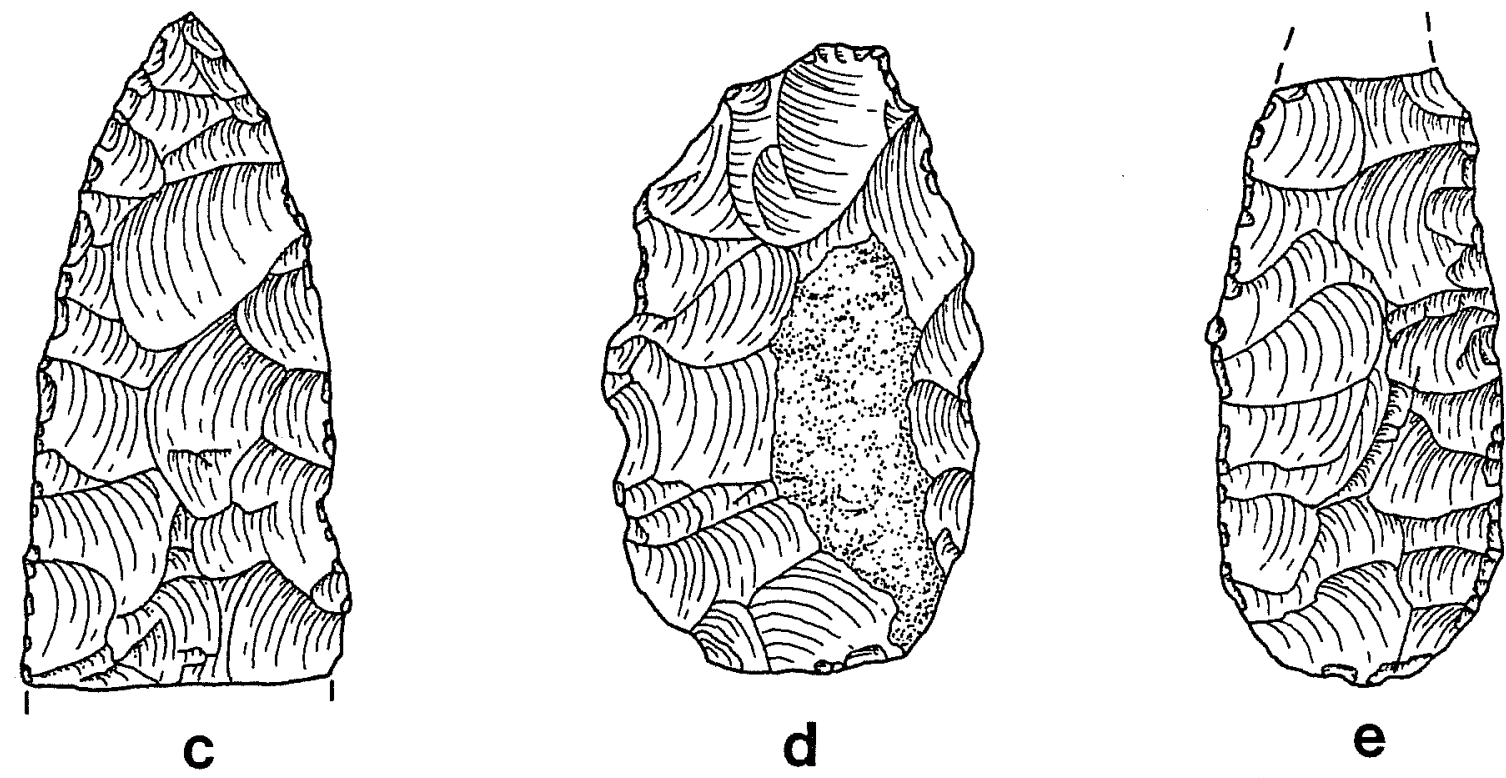

Figure 3. Artifacts Recovered Within and Adjacent to the Arco Rightof-Way. a, unifacial scraper; b. Tortugas point; $c$, thin biface; $d$, thick biface; e, Abasolo point. 
Monitoring of the machine trenching at this locale failed to identify any cultural materials. Additionally, no artifacts had been identified in the right-of-way during the pretrenching survey by the CAR-UTSA archaeologist. The vertical soil profile following trenching was very similar to that reported for Arco Locale No. 1. The only major difference consisted of several strata of bedded gravels intermixed with mussel she11 in the upper portions of the profile (Fig. 2,b). There was no caliche or sandstone strata evident in this profile; the lowest portions of the profile consisted of a lense of gravels at least $25 \mathrm{~cm}$ in thickness.

Brown (1986:6) suggested that the cultural materials at this locale were found in a secondary context--possibly eroded from the uplands west of the right-of-way. The nearby uplands were closely inspected for a distance of ca. 300 feet west and 150 feet east of the pipeline center 1 ine. Vegetation in both areas was dense, consisting of scrub brush, prickly pear cactus, mimosa, and mesquite, which 1 imited ground visibility. Intensive surface survey failed to identify a single flake. It would appear that the materials identified by Brown's survey did not erode downhill nor had they been pushed uphi11 by wave action. No alternative hypothesis for their presence can be offered by this project.

Arco Site No. 3 (4l ZP 109)

Arco Site No. 3 is located on the eastern side of the Beckwith Arm of Falcon Reservoir near the extreme eastern end of the pipeline corridor on federal 1 and (Fig. 1). Brown (1986:7) recovered two artifacts from this locale (within a 3000-square-foot area). He noted that the general vicinity of this locale had been disturbed by heavy machinery, and the site had been heavily impacted prior to his survey (ibid.).

During the pretrenching survey by the CAR-UTSA archaeologist, the Arco engineer had noted the location for this locale as in the vicinity of survey stations 101+00 and 102+00. No evidence for the presence of a site was found within or adjacent to these survey stations. However, near station $86+00$, a 1 arge surface scatter of 1 ithic debitage and several dart points (Fig. $3, b, e$ ) were identified. Trenching at station $86+00$ failed to produce any cultural materials in the backdirt (Fig. 2,c). Trenching at survey stations $101+00$ to 102+00 was not observed due to the breakdown of the trenching machine. Based on the evidence observed in the field, either Arco Site No. 3 was misplotted in the report by Brown (1986:Fig. 2) or the site at station 86+00 had been overlooked during his survey. Due to the size of the area exhibiting cultural materials and their proximity to the pipeline center 1 ine, the former is most probably the case. However, there was no evidence of surface disturbance by heavy machinery for portions of the site outside the right-ofway as had been noted by Brown (ibid.).

The 1 argest portion of the site at survey station $86+00$ is situated on the easternmost portions of the right-of-way and extends at least 200 feet east along a sandstone ridge. Site size is estimated at 200 feet by at least 100 feet. Evidence at the site suggests that the lower portions have been exposed by wave action from the waters in the Beckwith Arm of the reservoir. The uppermost portion of the site, densely covered with mesquite (up to 
10 inches in diameter), appears to be intact and above normal pool level (301 feet above MSL).

Cultural materials at the site consisted primarily of 1 ithic debitage $(75$ flakes; on ly two of which were in the right-of-way). Two nearly complete Archaic dart points, an Abasolo and a Tortugas point (Turner and Hester 1985:61 and 152, respectively), were also recovered (Fig. 3,b,e), along with a unifacial scraper (Fig. 3,a). The scraper is finely crafted from a primary flake and exhibits extensive use wear along the working edge. Use wearrelated edge damage consists of edge rounding and a few isolated striations perpendicular to the working edge at 40X magnification. These types of edge modifications suggest that the mode of use for this tool would have been in an adzelike fashion, versus a sawing or cutting type of motion. The basal portion of a unifacial gougelike tool (not illustrated) was also recovered; similar specimens have been noted by this author roughly 30 miles north of this site in a nearly identical topographic and environmental setting.

This site yielded the widest range of 1 ithic materials from all sites within the Arco right-of-way. It is suggested that this site may represent the remains of a temporary campsite used during the Middle to Late Archaic (ca. 2000 B.C.-A.D. 1000). No burned rock was evident anywhere within the area surveyed. This site stands in contrast to the other three "sites" mentioned in this report which appear to be no more than 1 ithic procurement areas or "chipping stations." At these other "sites" material evidence is 1imited to 1 ithic debitage, suggesting that the initial stages of stone tool production (i.e., dart points, scrapers, gouges) were occurring without associated campsite activities.

CAR-UTSA Site No, 1 (41 ZP 108)

Site 41 ZP 108 is not entirely located on federal 1and; however, portions of it are located within the Arco right-of-way between survey stations $15+38$ and 17+38 (Fig. 1). The site was first identified by the presence of several tertiary flakes along the fence 1 ine adjacent to the right-of-way. A total of seven flakes was found within the right-of-way between the two survey stations. The location for this area is an up 1 and ridge which gradual1y slopes to the west. The area west of the right-of-way (up to 250 feet) was surveyed in an attempt to isolate the main site area; the area east of the fence 1 ine was not surveyed. The area west of the right-of-way contained localized concentrations of 1 ithic debitage in shallow depressions and sma 11 arroyos. Backdirt piles from four different armadillo burrows each contained four or more flakes. Most of the flakes in the general area appeared to be initial reduction, hard-hammer $f 1$ akes (only one of $80+$ appeared to have been produced by a soft hammer or billet).

Several large, complete musse 1 shel 1 valves and numerous fragments were noted in the area west of the Arco right-of-way. This area also contained numerous eroded grave1s $(3-10 \mathrm{~cm}$ in length), of which on $1 \mathrm{y}$ a very few (three) exhibited any evidence of deliberate modification. The ground surface in this area is generally unvegetated, deflated, and heavily eroded by sheetwash. Intensive survey failed to identify or isolate a single discrete site area within or adjacent to the right-of-way. Machine trenching between 
survey stations $15+38$ and $17+38$ was closely monitored. Backdirt from trenching failed to produce any cultural materials.

\section{SUMMARY AND RECOMMENDATIONS}

The archaeological locales, initially identified by Brown (1986), within the Arco pipeline construction right-of-way were not adversely impacted by the machine trenching. No cultural materials were identified in the backdirt at any of the locales during archaeological monitoring. No further work is recommended at any of the three locales trenched.

Several comments regarding these areas need to be made. Brown (1986:6) was hesitant, and rightly so, to call these three areas "sites" given the level of recovery for cultural materials at each locale. This survey has demonstrated that Arco Locale No. 1 is not within the Arco right-of-way, rather it appears the main site area is approximately 100-250 feet west of the right-of-way. No evidence was found by this project that would verify the existence of a site at survey stations 48+00-49+50 (Arco Loca 1 e No. 2). This locale should not be considered as an archaeological site unless additional evidence can be found at some future date. Arco Site No. 3 (41 ZP 109) was apparentiy misplotted by the original survey as no evidence for its presence could be found at the location noted by Brown. If it was not misplotted, then the site at survey station $86+00$ had been overlooked during the initial survey. The CAR-UTSA Site No. 1 (4I ZP 108) was not recorded during the earlier survey. Either it was overlooked during the previous survey or it was not recorded because it was not located on federal 1 and, even though portions of it are within the Arco right-of-way.

Sites $41 \mathrm{ZP} 108$ and $41 \mathrm{ZP}$ 109, both within the Arco right-of-way, are not considered to be significant cultural resources in that they are not deemed potentially eligible for nomination to the National Register of Historic Places, nor can they be designated as a State Archeological Landmark. 


\section{REFERENCES CITED}

Brown, K. L.

1986 An Archaeological/Historical Impact Assessment for a Gas Pipeline, Zapata County, Texas. Department of Anthropology, The University of Houston.

Council of Texas Archeologists (CTA)

1981 Guidelines for Cultural Resource Management Reports. Council of Texas Archeologists, Newsletter 5(2).

Hester, T. R., R. F. Heizer, and J. A. Graham

1975 Field Methods in Archaeology. 6th edition. Mayfield Publishing Company, Palo Alto, California.

Turner, E. S. and T. R. Hester

1985 A Field Guide to Stone Artifacts of Texas Indians. Texas Monthly Press, Austin. 
